\title{
DEPOSITIONAL ENVIRONMENTS OF SUPRACRUSTAL METASEDIMENTARY SEQUENCE AND POSSIBLE MODEL FOR ZINC MINERALIZATION OF RIO ClARo AREA, RIO DE JANEIRO STATE (BRAZIL)
}

\section{Ronaldo Mello Pereira ${ }^{1 *}$, Ana Caroline Dutra ${ }^{2}$, Francisco Silva ${ }^{3}$, Marcelo Salomão ${ }^{1}$ ANd Mauro Geraldes ${ }^{1}$}

1 Faculdade de Geologia da Universidade do Estado do Rio de Janeiro, UERJ. Rua São Francisco Xavier, 524, sala 2017A, Rio de Janeiro, Brazil, CEP 20550-900.ronaldo.mello@pq.cnpq.br; ronaldo.mellouerj@gmail.com; salomao.mss@gmail.com; mauro.geraldes@gmail.com 2 Graduação em Geologia. Universidade do Estado do Rio de Janeiro. Rua São Francisco Xavier, 524, sala 2017A, Rio de Janeiro, Brazil, CEP 20550-900. anacarolinedutra@yahoo.com.br

3 Departamento de Geologia do Instituto de Agronomia da Universidade Federal Rural do Rio de Janeiro. Campus Seropédica. Brazil. fjosilva@ufrrj.br

* CorResPonding AUTHOR, ronaldo.mellouerj@gmail.com

Received on 07 September 2016

Received in revised form on 03 October 2016

Accepted on 11 October 2016

Editor:

Maria Antonieta da Conceição Rodrigues, Universidade do Estado do Rio de Janeiro, Brazil
Citation:

Pereira, R.M., Dutra, A.C., Silva, F., Salomão, M., Geraldes, M., 2016. Depositional environments of supracrustal metasedimentary sequence and possible model for zinc mineralization of Rio Claro area, Rio de Janeiro State (Brazil). Journal of Sedimentary Environments, 1(3): 348-359

Lídice I, II and III. Lídice subunits I and II exhibit quartzite interleaved with pelitic rocks and graphite gneiss, suggesting deposition in deeper environments of the basin, probably related to turbidity currents. In Lídice III subunit, more carbonated and with more quartz, limestone quartzite stand out, which enclose mineralized zones, reflecting depositional environment in shallow platform, possibly involving evaporitic environment, sabkha type. Sulfite mineralization of Rio Claro, associated with platformal rocks intensely metamorphosed and deformed, as well as its local geological context, features similarities with sedimentary exhalative deposits (SEDEX) Zn-Pb-Ag model, Shuswap and Monashee type, present in Monashee and Shuswap Complexes of British Columbia in Canada.

to the formation of quartzite with magnetite, considered banded iron formations. São Roque Unit is composed of four subunits (São Roque I, II, III and IV) and presents a typical pattern of deposition of low energy environments, in marine deep basins. Gondite, coticules levels and (Mn)almandine present in the local gneiss mark the manganese exalative contribution in that unit. Lídice unit has different sedimentation palaeoenvironments and is subdivided into
Keywords: Limestone quartzite. Zn-Ag mineralization. SEDEX. 


\section{Introduction}

The pyrite deposit of Rio Claro, located in the southwestern region of the State of Rio de Janeiro, was discovered and exploited in the 1930s of the last century (Abreu and Oliveira, 1934). In the mid-1970s, a geological mapping was made, followed by geochemical analysis of collected materials in drainages, geophysical induced polarization and magnetometric resistivity, ending up prospective studies with a diamond drilling campaign (Riofinex, 1977). Some bodies mineralized in $\mathrm{Zn}$ were selected in the areas of Colengo, Córrego Paraguai, Rio das Canoas (Fazenda Rio das Canoas) and Córrego Passa Dezoito (Passa Dezoito Farm), in which the sulfide mineralization consists of pyrite (Córrego Paraguai), pyrrhotite + pyrite (Colengo, Rio das Canoas and Passa Dezoito) and minor amounts of sphalerite, chalcopyrite, galena and silver, which occur scatteredly in lithotype called limestone quartzite (Riofinex, 1977).

Mineralization control was deemed lithologic and always localized close to the contact between the lenticular bands of quartzites, limestones and garnet-biotite porphyroblastic gneiss (Riofinex, 1977; Chaves, 1987). Shafts with sulfide filling brittle structures are observed only in the areas of Córrego Paraguai and Colengo (Riofinex, 1977; Chaves, 1987).

Reserves pointed to the subeconomical character of the prospectus, and the average content of $2 \% \mathrm{Zn}, 0.3 \% \mathrm{~Pb}$ and $50 \mathrm{ppm}$ Ag. In addition, the thinness and the lack of continuity of the mineralized layers contributed to the negative assessment of the prospectus (Riofinex, 1977). The measured and indicated reserves were 1,600 $\mathrm{t}$ (with $950 \mathrm{t} \mathrm{Zn}$ ) and 9,200 t (5,500 t Zn), respectively (Riofinex, 1977).

Sulfide mineralization was framed in different typological models: hydrothermal (Abreu and Oliveira, 1934), metamorphism contact (Sousa, 1939; Leonardos, 1942) and syngenetic origin (Suszczynski, 1975; Fonseca et al., 1979). Subsequent studies proposed Mississippi Valley models, but in higher metamorphic grade and taking as an example the deposits of Balmat-Edwards district, NY, USA (Riofinex, 1977) and exhalative sediments (Chaves, 1987).

\subsection{Objective}

This work proposes a review of the geology of the Rio Claro region, in order to define the possible depositional environment and the type of mineralization. From the stratigraphic sequence defined by Riofinex (1977), consisting of ten units, the only units considered for this study were Valadão, São Roque and Lidice units, because they present relevance to the identification of their formations palaeoenvironments and because the latter holds sulfide mineralization. The basement rocks and Lorena, Passa Dezoito Gneiss, and Passa Dezoito Quartzite unities have been described to better compose the geological setting of the area.

\section{Geotectonic and structural compartimentation}

The proposed tectonic subdivision for the central segment of the Ribeira Belt (Figure 1) comprises four tectonic-stratigraphic terrains stacked toward São Francisco Craton during the orogenic events that occurred between 605 and 580 Ma: Oriental Terrain, Occidental Terrain, Klippe Paraiba do Sul and Cabo Frio Terrain (Heilbron et. al., 2000, 2004).

Rio Claro region, located in Occidental Terrain, presents tectonic intercalations among 1.7 billion year-old prefoundation rock (Juiz de Fora Complex) and Neoproterozoic metasedimentary rocks of Andrelandia Megasequence, metamorphosed to granulite facies.

The lithostratigraphic units present there are arranged in NE-SW direction, in accordance with Ribeira Belt general direction (Heilbron et al., 2007). The lithological layering is concordant with the foliation, which is significant in the metapelitic and incipient rocks in metapsamitic rocks. The dives range from $30^{\circ}$ to $70^{\circ}$ to $\mathrm{NW}$ and NNW.

NW-SE and NNE-SSW lineaments are observed in the region, much of which was utilized for the installation of local drainages. The most important one is in the western portion of the area and was called Rio Claro Lineament. Probably, it corresponds to some crustal discontinuity, since it apparently separates terrains with different geological characteristics.

In the area, parasitic folds, crenulations in migmatitic gneiss, ptigmatic folds can be observed, showing differences of competence in calcissilicatic gneiss. Horizontal folds of metric scale, impure quartzites and calcissilicatic rocks also can be found. Folds like drag folds are particularly observed in rocks of metasedimentary units (Passa Dezoito and Lídice), which are in the vicinity of Rio Claro lineament (Dutra, 2013). 


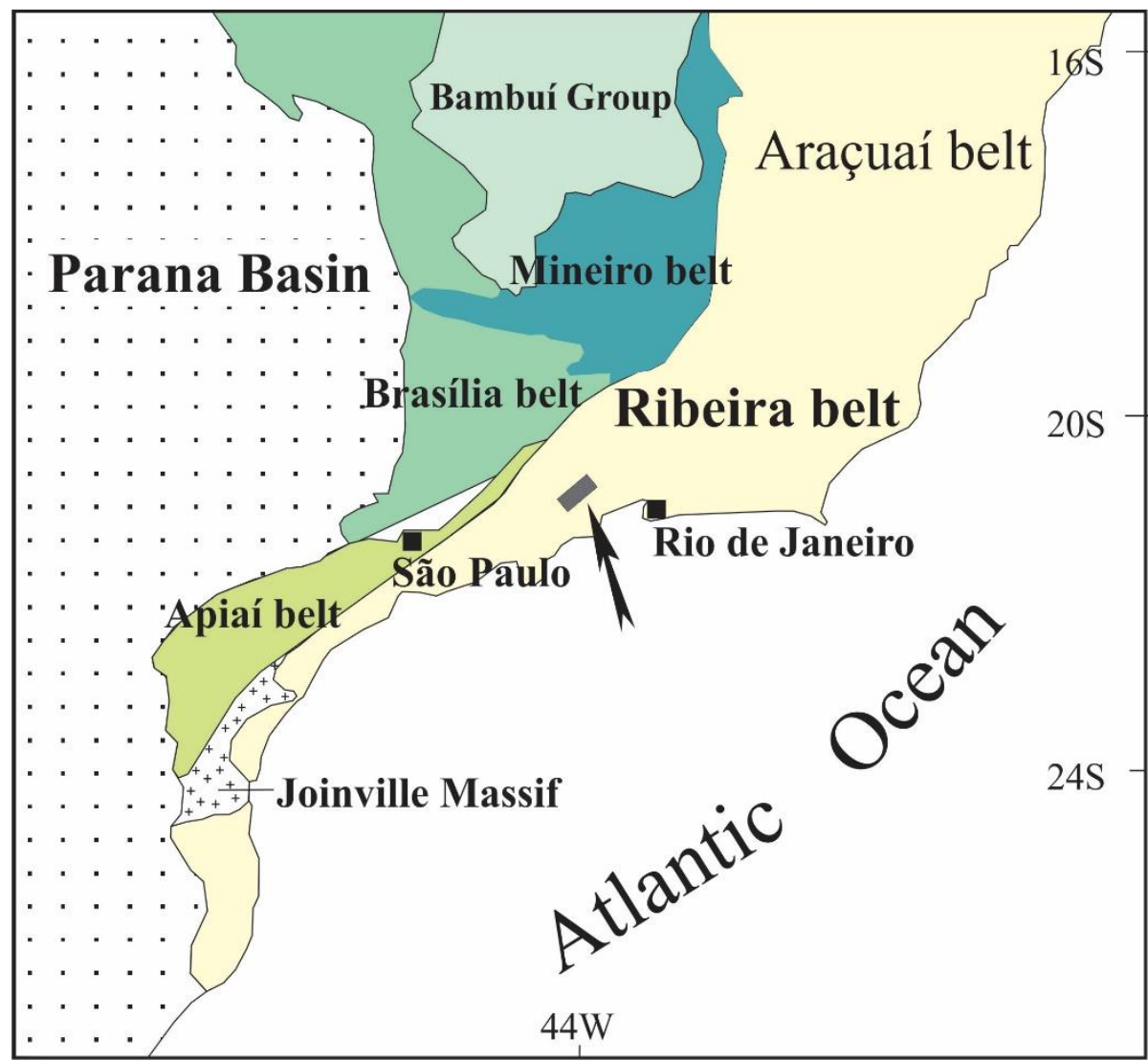

Fig. 1. Tectonic State of Rio Claro region in relation to Ribeira Belt. The arrow indicates the position of the studied area (Adapted from Heilbron et al., 2004).

Granitic rocks, positioned in these lineaments, indicate that some of that correspond to shear zones. In fact, there are several evidences that indicate this type of structure: milonitic macroscopic features, intense stretch of minerals, porphyroblasts of plagioclase and orthoclase, quartz ribbons with undulatory extinction and subgrains mats.

Two magmatic pulses occurred in the region. The oldest, Neoproterozoic, post-metamorphic, was responsible for the intrusion of various bodies of isotropic granites.

These bodies have light gray color, fine to medium grained, gray-pink microcline crystals, biotite as main mafic mineral and injection of rich pegmatites in black tourmaline (schorl). In the vicinity of Rio das Canoas / Fazenda Rio das Canoas, sulfide mineralization occurs in the form of pyritic quartz veins that took advantage of the spaces generated by the shearing process to fill the rocks fractures. These pyritic veins are related to later hydrothermal remobilization events, possibly associated with these granitic bodies (Chaves, 1987).
Several diabase dykes cut all units that are present in the area and are concordant with the orientation of regional lineaments, particularly the one of Rio Claro. These rocks correspond to younger magmatic pulse. Those rocks mark a more recent phase of regional tectonic activity, which is probably related to taphrogenesis that established coastal marginal basins of southeastern Brazil, as proposed by Chang et al. (1992).

\section{Material and methods}

\subsection{Study area}

The study area is located in the southern region of the State of Rio de Janeiro, the Rio Claro city, distant about 130 kilometers from the Rio de Janeiro city. In the region, ortogranulitic bodies (Heilbron et al., 1995, 2007) and rocks of supracrustal set (Dutra, 2013) occur. 
According to Heilbron et al. (1995, 2007), ortogranulites represent basement and belong to Juiz de Fora Complex, occurring in the shape of interdigitated tectonic slices with supracrustal rocks, separated by shear zones (Figure 2). These ortoderivade bodies have protholiths which may vary from types tonalitic to gabbroides.

Basic granulite occurs in the vicinity of Lidice and represents a gabbroide body of tabular form with four kilometers in length and thickness between 100 and 200 meters. Basically, it is a strongly magnetic type, in which the main ferromagnetic mineral is represented by titanomagnetite (up to $1.9 \% \mathrm{~V}_{2} \mathrm{O}_{5}$ ). Pyroxene $(80 \%$ ortho and $20 \%$ cline) and feldspars are its main constituents (Pereira et al., 2015).

Acid granulites, with tonalite composition, are found in exhibitions located near the town of São Marcos and Ribeirão das Lajes Reservoir. Overall, they have greenish color, medium-grained to coarse, compositional banding exposing quartz-feldspathic and mafic levels with pyroxene, amphibole, mica and magnetite (up to $8 \%$ of this mineral). Close contact with adjacent units display milonitic textures. Recent datings made in acid granulites by André (2014) have indicated Neoarchian age of $2.6 \mathrm{Ga}$ for those rocks, which are, therefore, older than previously thought.

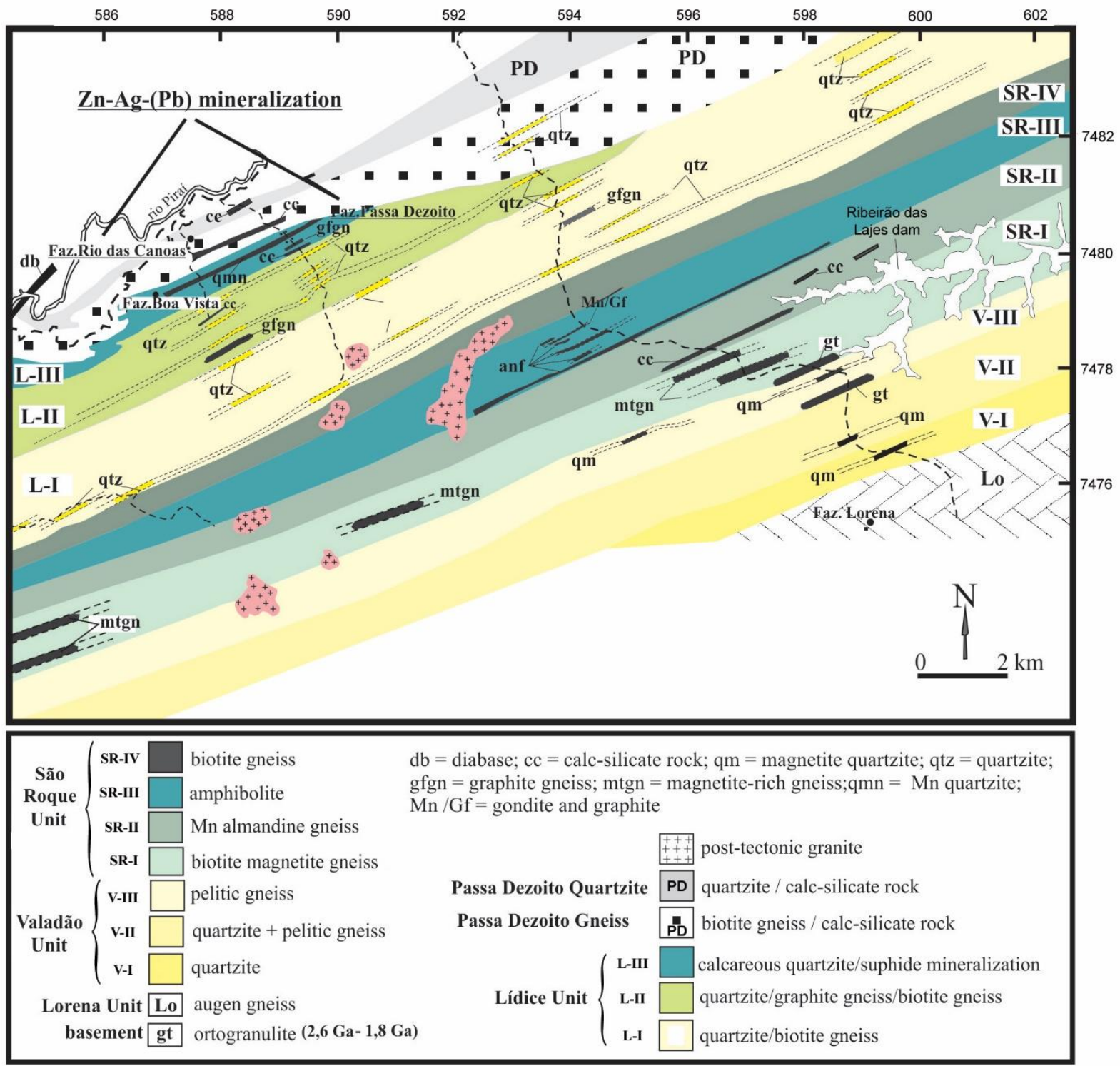

Fig. 2. Geological map of Rio Claro area, Rio de Janeiro. 
The supracrustal set displays metapelitic rock types of high-grade, mainly consisting of banded garnet-biotite gneiss, sometimes with sillimanite. Banded biotite gneiss, garnet-plagioclase gneiss, graphitic gneiss, rocks with manganese, calcissilicatic rocks, pure and impure quartzite, limestone quartzite, magnetite quartzite, sillimanite quartzites and amphibolites complement the remaining lithotype present in the area (Dutra, 2013). This supracrustal set, considered as belonging to Andrelândia Megasequence (Heilbron et al, 2007), can be divided into different informal lithostratigraphic units such as Valadão, São Roque, Lidice and Passa Dezoito (Riofinex, 1977; Chaves, 1987; Dutra, 2013).

Field activities involved geological remapping of the area and aimed the recognition of different palaeoenvironments of sedimentation of supracrustals rock, from a better petrographic and structural characterization of lithotypes cited in bibliography analyzed during this study. During the fieldwork, samples were collected aiming to petrographic, geochronological and mineral chemical analyses. The samples were physically prepared in Sample Preparation Geological Laboratory (LGPA), Faculty of Geology of State University of Rio de Janeiro (UERJ), with the production of thin sections and whole rock crushing.

Petrographic analyses (micro and macro) aimed to describe the mineralogical composition and textural characteristics of the samples. U-Pb analyses in zircon aimed to determine the crystallization age and to contribute to the understanding of the relationship between the investigated lithotypes. ICP-MS-MC-LA technique was used, by means of Neptune Laser Ablation ICP Mass Spectrometer Multicollector equipment, at Multi-User Environment and Materials Laboratory (Multilab), of Faculties of Geology and Physics at UERJ. This equipment allows isotopic precision analyses, contributing to compositional and textural studies of minerals for radiometric dating. The mineral grains are conditioned in a repository with resin, which are subjected to laser application with $4 \times 10^{4}$ counts per second (CPS) and 30 micrometers beam size. Samples of Lorena and São Roque Units were analyzed.

Mineralogical chemical analysis was performed using scanning electron microscope (SEM). This device provides high resolution electronic images, referring to the energy encoding emitted by electrons generated from the electron beam interaction with the samples analyzed. EDS sensor (Energy Dispersive X-ray Detector) captures the energy emitted in X-ray wavelength, due to the interaction of electrons of the mineral with the beam of the equipment. The quantity of released energy is characteristic of every atom, allowing the identification of chemical elements present in the target of the incidence of the electronic beam. The analyzed material corresponds to concentrations of ferromagnetic minerals (magnetite) of São Roque Unit and a granulite body.

The information obtained in the field was inserted in a georeferenced database and integrated to those present in the bibliography analyzed during this study. The achieved results will be presented hereafter.

\section{Results}

\subsection{Supracrustal Metasedimentary Sequence}

Lorena Unit is located at the base of the set of metasedimentary rocks (Figure 3) and corresponds to banded, coarse-grained gray biotite gneiss, with mineralogical composition represented by quartz, feldspar, and amphibole. It also presents significant mylonitic texture, leaving feldspar porphyroblasts in evidence, developing, in some portions of the rock, facoidal or augen texture. Probably, Lorena Unit derives from igneous protolith. U-Pb analyses by ICP-LA in zircons set Neoproterozoic age ranging from $710 \mathrm{Ma}$ to $618 \mathrm{Ma}$.

Superimposed on the orthogneiss of Lorena Unit, in abrupt contact, lies Valadão unit, which was divided into three subunits: psamitic (I), pelitic - psamitic (II) and pelitic (III). These subunits are in gradational contact with each other and all of them show the presence of thin layers stratiform magnetite quartzite.

Valadão I subunit corresponds to a 600 meter-thick quartzitic set, with white color, coarse to very coarse, formed essentially of recrystallized quartz with some muscovite and biotite, which provide a laminated structure for the rock. This quartzitic set is interspersed with thin layers composed by metapelitic rocks, represented by fine-grained biotite gneiss as well as quartzite with magnetite. The latter occurs as sets ranging between 1 and 1.5 meters of thickness, with over $21 \%$ of magnetite in its composition. Locally, it was observed a quartzite level with less than one-meter thick containing graphite.

In Valadão II subunit, which has an estimated thickness of 900 meters, there is a significant increase in metapelitic materials (biotite-gneiss and garnet-biotite gneiss) that merges with decimeter levels of magnetite quartzites. The latter has xenoblastic matrix, with elongated arrangement in the form of discontinuous strips and magnetite content of $29 \%$. 


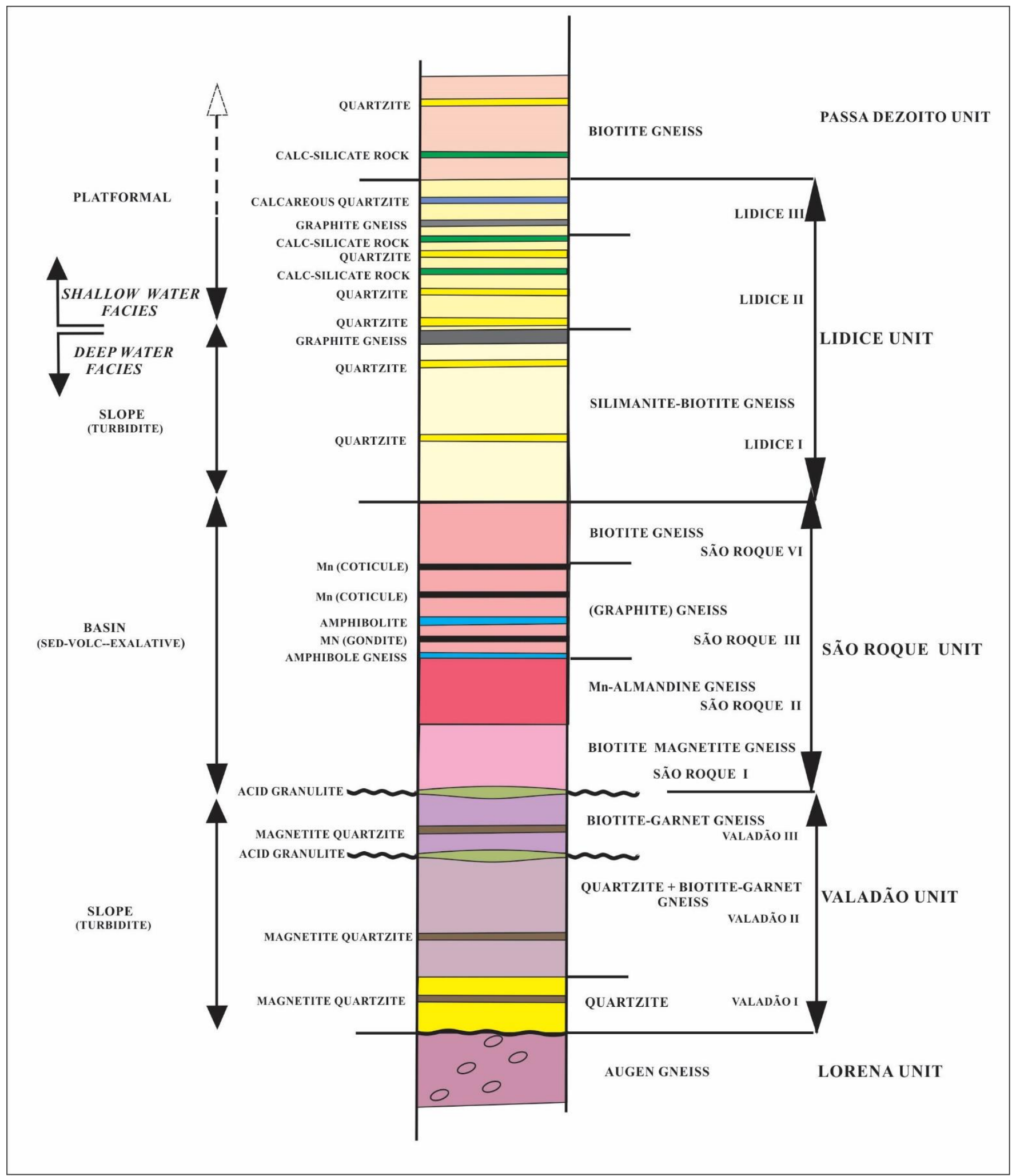

Fig. 3. Geological set of Supracrustal Sequence established from data generated by this study. 
Valadão III subunit is approximately 650 meter-thick, consisting essentially of garnet-biotite gneiss and biotite gneiss with intercalation of quartzite magnetite levels. Gneiss occurs in gradual contact, where there is a textural and mineralogical increase with garnet toward São Roque unit. Garnet-biotite gneiss consists of quartz, biotite, muscovite, garnet (almandine) and magnetite. Magnetite quartzite levels (up to $50 \%$ magnetite) form a set with 1.5 meter-thick and are interleaved in gneiss of this unit.

São Roque unit was divided into four subunits. São Roque I subunit occurs associated with granulitic bodies. This unit is represented by a magnetite-biotite gneiss set of fine-grained to coarse, with banding marked by mafic levels (biotite and hornblende) and felsic (quartz and feldspar). Magnetite occurs in disseminated or concentrated form, composing continuous and targeted levels according to the banding of the rock. The contents by weight of magnetite in the rock are up 7.0\%. Microchemical analyses in SEM-EDS of that magnetite indicated low levels of $\mathrm{Ti}(<0.5 \%)$ and $\mathrm{V}_{2} \mathrm{O}_{3}$ around $0.35 \%$. ICP-LA datings in zircons pointed to a predominantly Paleoproterozoic source, aged between 1.7 $\mathrm{Ga}$ and $2.2 \mathrm{Ga}$ and metamorphism registration at the edges of the grains between 583 and $619 \mathrm{Ma}$.

São Roque II subunit has approximately 800 meter-thick and is marked by the presence of fine-grained to coarse garnet-biotite gneiss, in which garnet crystals with centimetric dimensions are found. The weathering of garnet displays different colors, reflecting compositional variation. The crusts of ocher color, limonitic, cover almandine with low percentage of $\mathrm{MnO}(0.9 \% \mathrm{MnO})$. The crusts of black color cover Mn-almandine (from $1.5 \%$ to $3.3 \% \mathrm{MnO}$ ), whose percentage was obtained by SEM-EDS analyses in minerals. Quartzite sets are present as well as lenses and boudins of amphibolite and calcissilicatic rocks. Quartzite, when pure, is whitish, slightly laminated, composed predominantly of quartz and, subordinately, by muscovite. When impure, it is yellow, presenting biotite and feldspar. It forms tabular bodies of variable scale or even forms sets with up to 20 meter-thick.

São Roque III subunit, with an approximate thickness of 550 meters, differs from the previous subunit due to the strong presence of amphibolites and the greater intensity of staining of the rocks of this set by manganese oxides. It consists of a garnet-biotite gneiss with various intercalations of amphibolites, calcissilicatic rocks, gondite, besides the occurrence of thin levels of manganese and graphite gneiss. It occurs in gradual contact with São Roque I subunit and in abrupt contact with São Roque IV subunit.
São Roque IV subunit, with approximately 600 meters of thickness, is predominantly composed of banded biotite gneiss, coarse-grained, composed of quartz, plagioclase, Kfeldspar (microcline and orthoclase) and biotite. Porfiroblastic strips with centimetric crystals of microcline are found locally, as feldspar crystals of centimetric size and elliptical shape, which gives the rock an augen texture.

Lidice Unit is composed of three subunits (Lidice I, II and III), with contact among them gradually moving from pelitic to psamitic. Near the top of the unit, the contact has carbonate and silico-carbonate contents. This unit encompasses a lithology rather peculiar, in which the predominant lithologies are biotite gneiss interleaved with pure quartzite, sillimanite gneiss with graphite, calcissilicatic rock and a more carbonate set with thin levels of marble and limestone quartzite. The latter rock lithotypes were discovered through diamond drilling accomplished by company Riofinex (1977) and correspond to the rocks that have sulfide mineralizations.

Lidice I subunit has thickness around 1,300 meters and is characterized by the occurrence of impure quartzite and boudins of calcissilicatic rocks interleaved in a thick gneissic set with biotite and, subordinately, garnet. Sillimanite-garnet gneiss set with graphite occurs associated with this subunit. Garnet-biotite gneiss, sometimes associated with muscovite, generally has fine-grained and gneissic banding. In the eastern area, the grain is thick, displaying migmatitic features with centimetric crystals of almandine in leucossomatic portions. The quartzite of this unit are white, with coarsegrained and mineralogy consisting of quartz and some feldspar, muscovite and biotite, the latter being responsible for the appearance of lamination.

Lidice II subunit has an approximate thickness of 1,200 meters and is composed of biotite gneiss with little garnet, interleaved with various levels of quartzite and calcissilicatic rocks, as well as with a calcissilicatic gneiss set with 2.0 meters thick. The biotite gneiss has gray color, fine-grained, migmatitic compositional banding marked by alternations of quartz-feldspathic levels and levels of biotite and, subordinately, muscovite and garnet. Pyrite is disseminated by the rock, and, in some points, one observes outcrops with yellow-green alteration stains, characteristics of sulfide zones. Whitish quartzite forms tabular bodies with mediumgrained to coarse, being slightly stretched and laminated due to the presence of micaceous minerals. Muscovite, biotite and feldspar occur in varying proportions in that rock. Greenish calcissilicatic rocks and dark green to black amphibolites occur along this subunit, interleaved in the form of continuous bodies of variable thickness or as lenses 
and boudins. Lidice II subunit also features a set of graphitic sillimanite-biotite gneiss, with about 15 meters thick. In more schist portions of metapelitic, with quite sillimanite, graphite occurs in well-defined horizons, in concentrated form. In more psamitic portions of this subunit, both graphite and sillimanite are disseminated in the rock.

Lidice III subunit has about 500 meters thick and comprises various levels of quartzite, interleaved with biotite gneiss, calcilicatic rocks and marbles. Quartzites correspond to feldspathic and limestone quartzite; the latter is the host rock of sulfide mineralization. A thin magnetite quartzite set is also part of this association. The quartzite set have discrete lamination, medium-grained to coarse, being composed of quartz, biotite and little or no feldspar. Their colors range from white to slightly ocher depending on the alteration degree.

Although, in the previous and current works of geological mapping, significantly carbonate lithotypes have not been found in surface, their presence could be verified from the data obtained in drilling (Figure 4) carried out by Riofinex (1977). Limestone quartzite sets generally do not exceed 3 meters in thickness and have medium-grained to coarse, consisting of quartz $(64 \%)$ and calcite $(23 \%)$ associated with smaller quantities of clinopyroxene $(5 \%)$. The following minerals occur subordinately: plagioclase, orthoclase, scapolite, hornblende, titanite, garnet and green spinel.

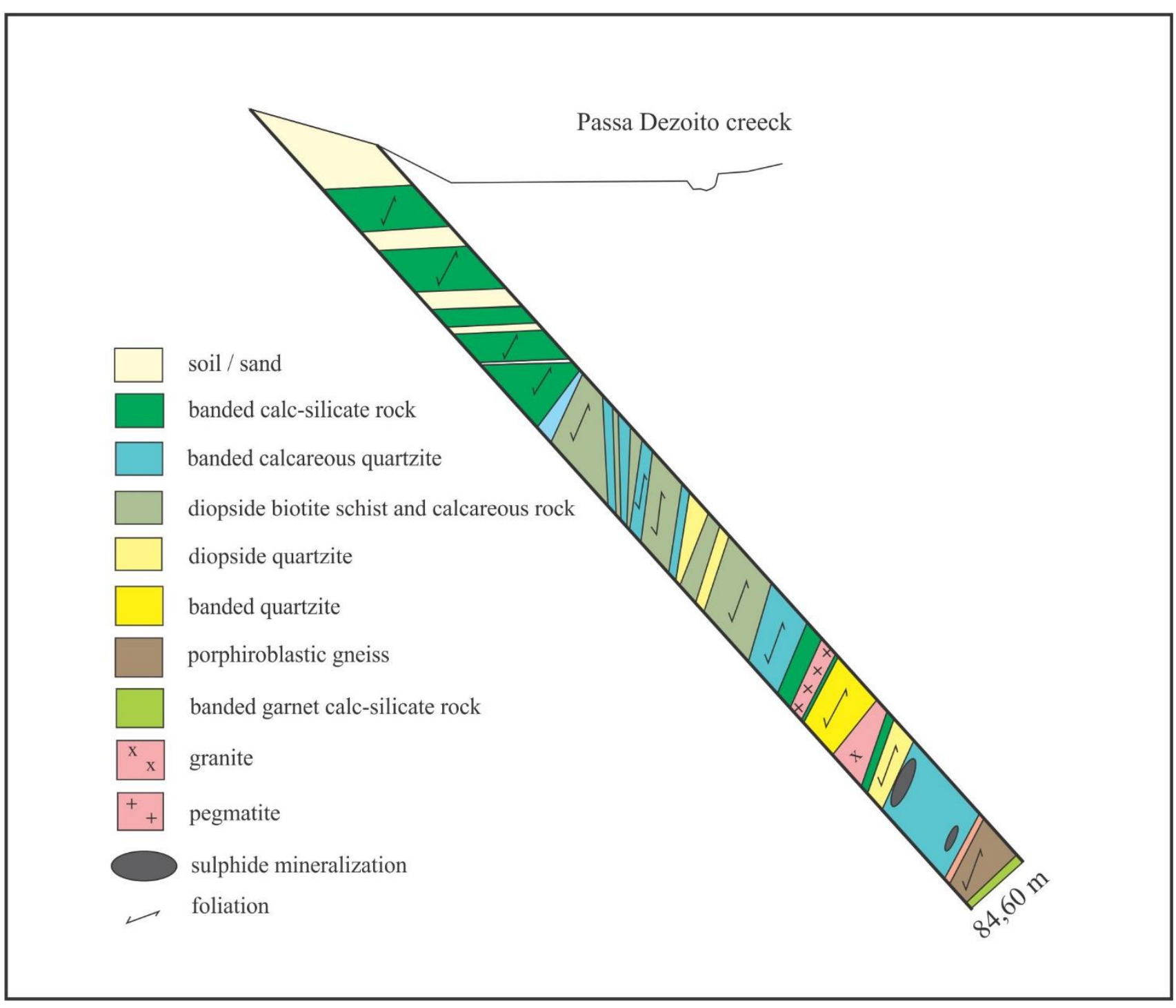

Fig. 4. Schematic section of Lídice III subunit based on drilling carried out by Riofinex (1977). 
Overlapping units to Lidice unit encompass the sequences represented by Passa Dezoito Gnaiss and Passa Dezoito Quartzite. The first unit consists of biotite gneiss and sillimanite-garnet-biotite gneiss, both medium-grained and arranged with gradual contact. The second unit, Passa Dezoito Quartzite, consists of impure quartzite, limestone quartzite, biotite gneiss, calcissilicatic gneiss and tabular set of calcissilicatic rocks with greenish gray color, granoblastic texture, thinly laminated. Despite the strong lithological similarity between Lidice III subunit and Passa Dezoito Quartzite unit, the latter is not mineralized.

\section{Discussion}

The sequence of metasedimentary rocks found in Rio Claro displays certain resemblance to the lithotypes normally associated with Andrelândia Megasequence. Therefore, both can be correlated. However, there is a significant variety of very unusual lithotypes in Rio Claro area, including metric strips of magnetite quartzite (interpreted as oxide facies banded iron formations), marbles, limestone quartzite, (Mn)almandine gneiss, magnetite gneiss, and graphitic gneiss. Calcissilicatic rocks, amphibolite, gondite and coticule (quartz-espessartite levels) are added to these lithotypes, which probably reflects a typical association of marine basins with variations in deposition environments (shallow to deep), with influence of submarine volcanic exhalations. These lithotypes are particularly associated with Valadão and São Roque units, which are part of the footwall of Lidice unit that limits the sulphide mineralization present in the region of Rio Claro.

Valadão Unit corresponds to an association of sedimentary rocks where quartzite sequences interleaved by pelitic rocks with biotite is observed. At the top of the unit, more aluminous gneiss occurs, with higher amounts of garnet, reflecting depositional environment of shallow to transitional platform, in the context of epicratonic basins (Sangster, 1990). Quartzite with magnetite that occurs interleaved in this unit probably represents some exhalative contribution to this set.

The thick quartzitic set of Valadão I subunit presents small variations in the mineralogical composition of the rock, consisting of more than $95 \%$ of quartz. Despite the lack of primary structures, probably obliterated by metamorphism, its sedimentary environment can be characterized as shallow platform, with a high degree of selection and high energy, associated with costal or coastal environments. The absence of conglomerates associated with the basal quartzite set may indicate a greater distance from the shore line.
On the other hand, the gneiss lithotypes of upper subunits (Valadão II and III) mark a first cycle of sinking of the platform, resulting in deposition of aluminous clay sediment in a deeper portion of the basin, perhaps related to transitional platform. These subunits were considered to be derived from graywackes and turbidites. The existent quartzite corresponds to thin strips and typically discontinuous and may derive from occasional turbidite flows, which may explain its scarcity in Valadão II subunit.

The São Roque unites composed by paragneiss with magnetite, biotite and garnetiferous, which are interlayered with calcissilicatic rocks, boudins and amphibolites and manganese levels. The rocks correspond to a combination of lithotypes representative of deep marine environment (Lydon, 1995; Yang et al., 2004). São Roque II and III subunits mark the presence of manganese associated with sedimentary sequence. Manganese is found both in almandine (up to $3.0 \% \mathrm{MnO}$ ) of paragneiss and in thin layers of coticule/gondite. This association highlights the contribution of exhalative submarine hydrothermal processes as the main source of $\mathrm{Mn}$ associated with this subunit. The amphibolites interleaved with this sequence also contribute to the interpretation of palaeoenvironment, making clear the relationship of sedimentary rocks with the marine substrate (Large et al., 2005).

Garnet gneiss (with or without sillimanite) of São Roque IV subunit is considered as derived from clayey sediments deposited in regulated environments basically by calm flows, with monotonous character, alternated by only turbiditic sedimentation pulses, expressed by quartzite sets that are arranged sporadically in this subunit (Sangster, 1990).

In stratigraphic context, Lídice unit represents a sedimentary sequence with strong features associated with shallowing cycle, which begins with a succession of metapelitic at the base, indicating deep environment. Gradually, Lídice unit displays shallower environment towards to its top. Metapsamitic facies mark a shallower shelf environment. The quartzite lithotypes may be associated to shallow environment, while gneiss lithotypes may be originated from arkose that, according to Riofinex (1977), has its origin connected to volcanic debris.

Lídice I subunit presents a metapelitic succession interleaved with layers of quartzite, suggesting deposition in deeper environment of the basin, associated with rhythmic deposition cycles and derivatives of turbidity currents. The significant presence of quartzite and calcissilicatic sets associated to Lídice II subunit can indicate a more proximal deposition and a little shallower water. However, the graphite gneiss present in this subunit, considered as a black 
shale due to its carbon content $\geq 1 \%$ (Tourtelot, 1979), may reflect a deposition in calm and anoxic environment, typical of basin bottom (Biondi, 2003).

Towards the top of Lidice Unit (Lidice III subunit), there is a gradation of facies related to a shelf environment increasingly shallower, in which carbonate rocks and, probably, evaporitic rocks could be included.

On surface, due to weathering alteration to which different lithotypes constituents of this subunit were submitted, the most carbonated horizons cannot be recognize. For example, in places where it is expected that mineralized limestone quartzite outcrops, it is observed a well-stratified set marked by alternating dark levels impregnated with manganese oxides (secondary) and light levels with quartz. This set, in the field, was informally called manganese quartzite. It should be indicated that, during the geochemical field work in detail (soil sampling) carried out by Riofinex (1977), there was a close association of $\mathrm{Zn}$ with $\mathrm{Mn}$, which, can reinforce the hypothesis set out in this work that and manganese quartzite corresponds to the same lithotype.

The origin of this manganese is still controversial. It can be the product of percolation and, thus, its origin may be related to manganese leaching of cretaceous diabase dykes that cut the supracrustal sequence. It can also correspond to weathering of thin carbonated levels that contain some Mn (Mn dolomite / kutnoherite?), possibly associated with limestone quartzite sets.

Deposits of SEDEX type are developed in sea basins going gradually to transitional environment associated with the ocean floor. Tentatively, carbonaceous shale, dolomite and micritic limestone found in SEDEX deposits (Sangster., 1990; Large et al., 2005) should be interpreted, respectively, as gneiss with sillimanite and graphite of the Lídice II subunit and calcissilicatic rock and calcareous quartzite of Lidice III subunit.

Regarding the origin of the deposit of $\mathrm{Zn}-\mathrm{Ag}$ of Rio Claro, it can be pointed out that the comparison with Balmat deposit, currently regarded as SEDEX type (Larivière and Gauthier, 2007), does not seem to be so evident. A justification may be the lack of a predominantly carbonate set and of thick levels of anhydrite associated with the sedimentary sequence that hosts the deposit in Rio Claro (deLorraine, 2001).

Limestone quartzite of Lidice III subunit corresponds to the main host rock of sulfide mineralization of Rio Claro. Rocks of this same type have been described in Jantland, Sweden (Dahlqvist and Calner, 2004) and in certain deposits of small size of $\mathrm{Zn}-\mathrm{Pb}-\mathrm{Ag}$ found in British Columbia, Canada (Höy, 1985; Thompson and Daughtry, 2000).

Based on the Canadian deposits considered as variations of classic zinc SEDEX deposits, and classified as a $\mathrm{Zn}-\mathrm{Pb}-$ Ag Shuswap type system, it was sought, then, a possible analogy to the deposit of Rio Claro area. Big Ledge and Sherpa deposits occur in platformal rocks intensely metamorphosed and deformed of Monashee and Shuswap Complexes of British Columbia that, as in Rio Claro, are mainly made of limestone quartzite, sillimanite gneiss, calcissilicatic gneiss, quartz-feldspar gneiss and calcissilicatic rocks (Höy, 1985). In these deposits, the presence of scapolite (marialite member), associated with limestone quartzite, suggests the participation of halite in the composition of these rocks, which is an indicator of evaporitic conditions for the formation of quartzite (Ramsay and Davidson, 1970; Höy, 1987; Tysdal and Desbourougn, 1997; Rosen et al 2005). Scapolite is also present in carbonate rocks of Rio Claro, although one can not say that it is the marialita member.

In SEDEX deposits, pyrite (associated to sphalerite and galena) represents in general the most common sulfide (Large et al., 2004), which in part is consistent with what is found in the deposit of Rio Claro. Nevertheless, pyrrhotite predominates over pyrite in the deposits of Shuswap type (Höy, 1985). This feature is also found in the deposit of Rio Claro, where the presence of pyrrhotite is remarkable and predominant in the mineralized bodies of Rio das Canoas and Passa Dezoito. Although the available information does not allow to make safe considerations regarding the origin of the deposit of Rio Claro, it is considered here that it has characteristics of $\mathrm{Zn}-\mathrm{Pb}-\mathrm{Ag}$ system of Shuswap type, such as that found in deposits of Sherpa, Big Ledge, Jordan River and Colby in British Columbia, Canada (Goodfellow and Lyndon, 2007; Höy, 1987).

\section{Conclusion}

Overall, Valadão Unit was considered as a turbidite sequence with influence of underwater hydrothermal exhalations, which led to the formation of quartzite with magnetite, considered as banded iron formations.

The lithotypes of São Roque unit reflect a deposition pattern typical of low energy environments, in marine basin bottom. The association of rocks of this unit presents exhalative contributions related to manganese, which is associated with gondite and coticule levels and is present in Mn-almandine of the local gneiss. 
In Lidice Unit, the lithotypes were interpreted as coming from two distinct sedimentation palaeoenvironments. Lídice I subunit, with quartzite and metapelitic, suggests deposition in deeper environments of basin, associated with rhythmic deposition cycles, derivative of turbidity flow. In Lidice II subunit, aluminous gneiss with graphite is observed, suggesting a pattern of calm sedimentation related to sea floor. Lidice III subunit reflects a deposition environment in a shallow shelf context, with possible associated evaporitic facies, probably sabkha type.

The deposit typology situated in Rio Claro region still cannot be established with certainty, but $\mathrm{Zn}-\mathrm{Pb}-\mathrm{Ag}$ mineralization in Sedex model of Shuswap type may be considered as the most probable typology.

\section{Acknowledgments}

The authors would like to thank JSE reviewers, Geotectonics Research Group (TEKTOS / UERJ) for their support in the field activities and Multi-User Environment and Materials Laboratory (Multilab) for processing the geochronological data.

\section{References}

Abreu, S.F., Oliveira, A.Q., 1934. Pyritas da Fazenda Rio das Canoas, Município de Rio Claro, Estado do Rio de Janeiro. In: Pyrita (Matéria Prima para Indústrias Químicas), Irmãos Pongetti, Rio de Janeiro, p. 20-41.

André, J.L.F., 2014. Comparação entre o Complexo Juiz de Fora e a Unidade granulítica Ponte de Zinco: geocronologia U-Pb em zircão (LA-ICPMS), geoquímica isotópica e composição das fontes geradoras. Tese de Doutorado. Programa de PósGraduação em Análises de Bacias e Faixas Móveis, Faculdade de Geologia da Universidade do Estado do Rio de Janeiro. $214 \mathrm{p}$.

Biondi, J.C., 2003. Processos metalogenéticos e os depósitos minerais brasileiros. Oficina de Textos, São Paulo, 528.

Chaves, M.L.S.C., 1987. Geologia das mineralizações sulfetadas da região de Lídice (Rio Claro, RJ). Dissertação (Mestrado). Universidade Federal do Rio de Janeiro, Rio de Janeiro.

Chang, H.K., Kowsman, R.O., Figueiredo, A.M., Bender, A.A., 1992. Tectonics and stratigraphy of the East Brazil Rift System - An overview: Tectonophysics 213, 97-138.

Dahlquist, P, Calner, M., 2004. Late Ordovician palaeoceanographic changes as reflected in the Hirnantian early Llandovery succession of Jantland, Sweden. Palaeogeography, Palaeoclimatology, Palaeoecology 210, 149164.

deLorraine, W.F., 2001. Metamorphism, polydeformation and extensive remobilization of the Balmat zinc ore bodies, northwest Adirondacks, New York. Society of Economic Geologists Guidebook Series 35, 25-54.

Dutra, A.C.D., 2013. Metalogenia em terrenos de alto grau: Contexto Geológico e Propostas para o modelo de geração das mineralizações sulfetadas de Rio Claro, RJ. Dissertação de Mestrado, Programa de Pós-Graduação em Análises de Bacias e Faixas Móveis, Faculdade de Geologia da Universidade do Estado do Rio de Janeiro. 124p.

Fonseca, M.J.G., Silva, Z.C.G., Campos, D.A., Tosatto, P., 1979. Carta Geológica do Brasil ao Milionésimo, Folhas Rio de Janeiro, Vitória e Iguape. Texto explicativo. MME /DNPM, Brasilia, 240 p.

Goodfellow, W.D., Lydon, J.W., 2007. Sedimentary exhalative (Sedex) deposits. In: Goodfellow, W.D. (ed.). Mineral deposits of Canada - A synthesis of major deposit-types, district metallogeny, the evolution of geological provinces, and exploration methods, Geological Association of Canada, p. 163-184.

Heilbron, M., Almeida, J.C.H., Silva, L.G.E., Palermo, N., Tupinambá, M., Duarte, B.P., Valladares, C., Ramos, R., Sanson, M., Guedes, E., Gontijo, A., Nogueira, J.R., Valeriano, C., Ribeiro, A., Ragatky, D., 2007. Geologia da Folha Volta Redonda- SF.23-Z-A-V, escala 1:100.000: nota explicativa integrada com Santa Rita do Jacutinga, Barra do Piraí, Angra dos Reis - Rio de Janeiro/São Paulo: MME/CPRM/UERJ.

Heilbron, M., Pedrosa-Soares, A. C., Campos Neto, M., Silva, L.C., Trouw, R., Janasi, V.A, 2004. Província Mantiqueira. In: Mantesso-Neto, V., Bartorelli, A., Carneiro, C.D.R., Brito Neves, B.B. (eds), Geologia do Continente Sul-Americano: Evolução da Obra de Fernando Flávio Marques de Almeida. [S.l.]: [S.n], v.11, p. 203-234.

Heilbron, M., Mohriak, W., Valeriano, C. M., Milani, E., Almeida, J.C.H., Tupinambá, M., 2000. From collision to extension: the roots of the South-eastern continental margin of Brazil. In: Talwani, Mohriak (Eds.), Atlantic Rifts and Continental Margin. AGU Geophysical Monograph Series 115, 354 pp.

Heilbron, M., Valeriano, C.M., Valladares, C.S., Machado, N., 1995. A orogênese Brasiliana no segmento central da Faixa Ribeira, Brasil. Revista Brasileira de Geociências 25, 245-266.

Höy, T., 1985. The Rebar and Sherpa lead-zinc occurrences, Shuswap Complex (82L110). British Columbia Geological Survey. Geological Fieldwork, paper 1936-1.

Höy, T., 1987. Geology of the Cottonbelt Lead-Zinc-Magnetite layer, carbonatites and alkali rocks in the Mount Grace area, Frenchman Cap Dome, Southeastern British Columbia. British Columbia Ministry of Energy, Mines and Petroleum Resources. Bulletin 80, 96p.

Large, R.R., Bull, S.W., McGoldrick, P.J., Walter, S., 2005. Stratiform and Strata-Bound Zn-Pb-Ag Deposits in Proterozoic Sedimentary Basins, Northern Australia. Society of 
Economic Geologists. Economic Geology, 100 ${ }^{\text {th }}$ Anniversary volume, p. 931-863.

Large, R., McGoldrick, P., Bull, S., Cooke, D., 2004. Proterozoic stratiform sediment-hosted zinc-lead-silver deposits of northern Australia. In Deb, M., Goodfellow, W.D., (eds.), Sediment hosted lead-zinc sulphide deposits, attributes and models of some major deposits in India, Australia and Canada. New Delhi, Narosa Publishing House, p. 1-23.

Larivière, J-F., Gauthier, M., 2007. Bryson (Québec): the Missing Link Between SEDEX Sulfide and Franklyn-type Startiform Hypogene Zinc Deposits. The Gangue, 93:1-10.

Lydon, J.W., 1995. Sedimentary exhalative sulphides (SEDEX). In: Eckstrand, O.R., Sinclair, W.D., Thorpe, R.I. (eds.), Geology of Canadian mineral deposit types, p. 130-152.

Leonardos, O.H., 1942. Depósitos de pirita de Rio Claro, Estado do Rio de Janeiro. Mineração Metalurgia 34, 183-187.

Pereira, R.M., Neumann, R., Salomão, M., 2015. Mineralizações de Fe-Ti-V em gabro granulitizado da região de Rio Claro (RJ). In. Simpósio De Geologia Do Sudeste, 14, Geosudeste. Campos do Jordão.

Ramsay, C.R., Davidson, L.R. 1970. The origin of the scapolite in the regionally metamorphosed rocks of Mary Kathleen, Queensland, Australia. Contributions to Mineralogy and Petrology 25, 41-51.

Riofinex do Brasil Geologia e Pesquisas Ltda., 1977. Projeto Rio Claro - Relatório final. 90 p. (unpublished).

Rosen O.M., Fettes D., Desmons J., 2005. Chemical and mineral compositions of metacarbonate rocks under regional metamorphism conditions and guidelines on rock classification. Russian Geology and Geophysics 46(4), 357-366.

Sangster, D.F., 1990. Mississippi Valley-type and SEDEX leadzinc deposits - a comparative examination. Transactions of the Institution of Mining and Metallurgy, section B, v. 99, p. B21B42.

Sousa, H.C.A., 1939. Piritas de Rio Claro, Estado do Rio de Janeiro. DNPM/DFPM, Rio de Janeiro, Boletim 34, 30p.

Suszczynski, E.F., 1975. Os Recursos Minerais Reais e Potenciais do Brasil e sua Metalogenia. Interciência Ltda. Rio de Janeiro, 534 p.

Thompson, R.I., Daughtry, K.L., 2000. Stratigraphic linkage of carbonate-rich units across east-central Vernon map area, British Columbia: are Kingfisher (Colby) and Big Ledge zinclead occurrences part of the same marker succession. Geological Survey of Canada, Current Research, 2000-A18 (on line).

Tourtelot, H.A., 1979. Black shale - Its deposition and diagenesis. Clay and Clay Minerals, 27(5), 313-321.

Tysdal, R.G., Desborough, G.A., 1997. Scapolitic metaevaporite and carbonate rocks of Proterozoic Yellowjacket Formation, Moyer Creek, Salmon River Mountains, central Idaho: U.S. Geological Survey Open-File Report 97-268, 26 p.

Yang, J., Bull, S., Large, R., 2004. Numerical investigation of salinity in controlling ore- forming fluid transport in sedimentary basins-Example of the HYC Deposit, northern Australia. Mineralium Deposita 39(5-6), 622-630. 